\title{
Pengaruh Pupuk NPK Pelet dari Kotoran Ayam terhadap Pertumbuhan dan Hasil Tanaman Kedelai (Glycine max l.) di Tanah Regosol
}

\author{
DOI 10.18196/pt.2014.026.74-80
}

\section{Anggi Aprian Murselindo}

PT. Indo Gunta Group,

Jl. P Jayakarta 103 Mangga Dua Selatan, Sawah Besar, Jakarta Pusat, Daerah Khusus Ibukota Jakarta 10730 Indonesia, e-mail:aprian_am46@yahoo.co.id

\begin{abstract}
ABSTRAK
Penelitian ini bertujuan untuk mengetahui dosis NPK pelet dari kotoran ayam yang tepat untuk meningkatkan pertumbuhan dan hasil tanaman kedelai pada tanah regosol. Metode penelitian yang digunakan yaitu dengan metode percobaan dilakukan di Green House dengan rancangan perlakuan faktor tunggal yaitu dosis NPK pelet dari kotoran ayam terdiri dari 5 perlakuan yang disusun dalam Rancangan Acak Lengkap dengan tiga ulangan yakni Pupuk Urea 50 kg /h, SP-36 150 kg/h dan KCl 100 kg/h (KO) ; NPK Pelet kotoran ayam 500 kg/h (K1) ; NPK Pelet kotoran ayam 1 ton/h (K2); NPK Pelet kotoran ayam 1,5 ton/h (K3) ; NPK Pelet kotoran ayam 2 ton/h (K4) ; NPK Pelet kotoran ayam 2,5 ton/h (K5). Hasil penelitian menunjukkan bahwa pemupukan dengan NPK pelet kotoran ayam dapat menggantikan pupuk rekomendasi sekaligus mensubstitusi Urea sebanyak 80\% SP-36 53,3\% dan KCI 60\% dalam budidaya kedelai pada tanah Regosol dan dosis 500 kg/h pupuk NPK pelet kotoran ayam lebih efektif terhadap pertumbuhan dan hasil tanaman kedelai. Kata kunci : Kedelai, Pelet kotoran ayam, Tanah regosol
\end{abstract}

\begin{abstract}
The research was conducted to determine the appropiate dose of NPK chicken manure pellets to increase the growth and yield of soybean crops in the regosol soil. The method of this research was used experimental research with single factor which is arranged in Completaly Randomized Design (CRD). The treatments were $50 \mathrm{~kg} / \mathrm{h}$ Ure + SP-36 $150 \mathrm{~g} / \mathrm{h}+\mathrm{KCl} 100 \mathrm{~kg} / \mathrm{h}$ (KO), NPK of chicken manure pellets $500 \mathrm{~kg} / \mathrm{h}$ (K1), NPK of chiken manure pellets 1 tons/h (K2), NPK of chicken manure pellets 1.5 ton/h (K3) NPK of chicken manure pellets 2 tons/h (K4), NPK chicken manure pellets of 2,5 tons/h (K5). The results of this research showed that NPK fertilization with chicken manure pellets can replace urea fertilizer recommendation simultaneously Multitusting as much as 80\% SP36 53,3\% and KC160\% in soybean cultivation on Regosol soil and a dose of $500 \mathrm{~kg} / \mathrm{h} \mathrm{NPK}$ chicken manure pellets was more efective to growth and yield of soybean.

Keywords: Soybean, Chicken manure pellets, Regosol
\end{abstract}

\section{PENDAHULUAN}

Kedelai (Glycine max L.) merupakan tanaman pangan yang penting sebagai sumber protein nabati untuk memenuhi permintaan dan kebutuhan masyarakat, sedangkan produksi dalam negeri belum mencukupi. Produksi kedelai nasional sepanjang 2013 sebesar 807.600 ton, sementara kebutuhan nasional mencapai 2,1 juta ton. Suswono, (2013) menyebutkan bahwa tantangan utama produksi kedelai adalah ketersediaan lahan, sedangkan rencana perluasan areal tanam baru sebesar 500.000 ha belum tercapai.

Salah satu kendala yang dihadapi dalam budidaya tanaman kedelai adalah kondisi tanah yang tingkat kesuburannya makin menurun. Walaupun tanaman kedelai dapat meningkatkan unsur hara $\mathrm{N}$ dalam tanah, namun untuk pertumbuhan yang optimal diperlukan kondisi tanah yang sesuai untuk pertumbuhannya (Manwan dan Sumarno, 1991). Untuk itu perlu dilakukan budidaya tanaman kedelai dengan memanfaatkan bahan organik sebagai campuran media tanam kedelai. Solusi yang tepat untuk mengurangi penggunaan pupuk sintetis sekaligus memperbaiki sifat fisika, kimia maupun biologi tanah yaitu penggunaan pupuk organik.

Salah satu jenis tanah marjinal di dae- 
rah beriklim tropika basah yang mempunyai produktivitas rendah tetapi masih dapat dikelola dan digunakan untuk usaha pertanian adalah tanah regosol (Hakim dkk., 1986 cit. Helmi, 2013). Penggunaan tanah regosol sebagai lahan pertanian dapat dilakukan, jika terlebih dahulu diperbaiki sifat fisika, kimia dan biologinya. Sifat fisika yang menjadi penghambat adalah drainase dan porositas serta belum membentuk agregat sehingga peka terhadap erosi (Munir, 1996). Hal ini menyebabkan tingkat produktivitas tanah regosol rendah sehingga diperlukan perbaikan secara fisika, kimia dan biologi (Helmi, 2013). Salah satu upaya pengelolaan lahan regosol yaitu dengan penambahan bahan amelioran, bahan organik dan pemupukan (Widjaya-Adhi \& Sudjadi, 1987 cit. Helmi, 2013).

Pupuk organik sangat bermanfaat bagi peningkatan produksi pertanian baik kualitas maupun kuantitas, mengurangi pencemaran lingkungan, dan meningkatkan kualitas lahan secara berkelanjutan. Penggunaan pupuk organik dalam jangka panjang dapat meningkatkan produktivitas lahan dan dapat mencegah degradasi lahan.

Sumber bahan untuk pupuk organik sangat beranekaragam, dengan karakteristik fisik dan kandungan kimia yang sangat beragam sehingga pengaruh dari penggunaan pupuk organik terhadap lahan dan tanaman dapat bervariasi.

Bentuk alternatif pupuk organik adalah bentuk pelet. Pelet memiliki keunggulan yang sama dengan POG (Pupuk Organik Granul), yaitu: kemudahan aplikasi, pengemasan, dan transportasi. Keunggulan yang lain adalah proses pembuatan yang lebih singkat dan mudah. Keunggulan penting POP (Pupuk Oganik Pelet) adalah dari sisi teknik dan biaya produksi. Tahapan produksi POP sangat singkat dan sederhana (Isroi, 2009). Pupuk organik pelet dengan komposisi C- Organik : 18,54\%, C/N Rasio : 15,32, pH : 8,51,
Kadar Air : 15 - 25\% mempunyai fungsi utama menggantikan peran pupuk anorganik.

Penelitian ini bertujuan untuk mengetahui dosis NPK pelet dari kotoran ayam yang paling tepat, untuk meningkatkan pertumbuhan dan hasil tanaman kedelai.

\section{BAHAN DAN METODE}

Penelitian dilakukan menggunakan rancangan perlakuan faktor tunggal yaitu dosis NPK pelet dari kotoran ayam terdiri dari 5 perlakuan, yang disusun dalam rancangan lingkungan acak lengkap dengan 3 ulangan. Perlakuan tersebut terdiri dari Pupuk Urea $50 \mathrm{~kg} / \mathrm{h}$, SP-36 150 $\mathrm{kg} / \mathrm{h}$ dan KCI $100 \mathrm{~kg} / \mathrm{h}$ (KO), NPK Pelet kotoran ayam $500 \mathrm{~kg} / \mathrm{h}(\mathrm{Kl})$, NPK Pelet kotoran ayam 1 ton/h (K2), NPK Pelet kotoran ayam 1,5 ton/h (K3), NPK Pelet kotoran ayam 2 ton/h (K4), dan NPK Pelet kotoran ayam 2,5 ton/h (K5). Setiap perlakuan diulang 3 kali, sehingga menjadi 18 unit percobaan, dan terdapat 3 tanaman sampel, 1 tanaman korban pada setiap ulangan sehingga terdapat $18 \times 4=72$ tanaman.

\section{Pembuatan Pelet Kotoran Ayam}

Pupuk NPK pelet kotoran ayam dibuat dengan bahan kotoran ayam 46\%, Urea 2\%, Sp36 $14 \%$, KCI $8 \%$, dan filler 30\%. Sehingga didapatkan pupuk pelet dengan grade 2,3 : 5,4: 6 . Caranya bahan dimasukkan ke dalam nampan, tambahkan air dan filler (lempung). Kemudian bahan yang sudah dicampur lalu dibentuk pelet dengan mesin peletizer.

\section{Penyiapan dan Pemeliharaan Tanaman Kedelai}

Tanah Regosol dikering anginkan selama seminggu dan dibersihkan dari kotoran kemudian disaring dengan mata saring $5 \mathrm{~mm}$. Tanah dimasukkan kedalam polibag $(40$ x $35 \mathrm{~cm})$ sebanyak $10 \mathrm{~kg}$. Setiap polibag ditanam dua benih 
kedelai dengan kedalaman tanam $5 \mathrm{~cm}$. Setelah satu minggu penanaman, dilakukan kegiatan penyulaman. Yang bertujuan untuk mengganti benih kedelai yang mati atau tidak tumbuh. Pengairan dilakukan 1 hari sekali selama 2 mmggu dan selanjutnya penyiraman dilakukan 3 hari sekali atau sesuai kebutuhan tanah.

Pemberian pupuk awal saat penanaman sesuai perlakuan yaitu Urea 0,3 g/polibag, SP-36 0,9 g/polibag $\mathrm{KCl} \mathrm{0,6} \mathrm{g/polibag} \mathrm{(KO),} \mathrm{NPK} \mathrm{pelet}$ kotoran ayam $3 \mathrm{~g} /$ polybag (K1), NPK pelet kotoran ayam $6 \mathrm{~g}$ /polybag (K2), NPK pelet kotoran ayam $9 \mathrm{~g}$ /polibag (K3), NPK pelet kotoran ayam $12 \mathrm{~g} /$ polibag (K4), dan NPK pelet kotoran ayam $15 \mathrm{~g}$ /polibag (K5). Pupuk diberikan dengan cara membuat lubang atau menugal tanah sekitar 7 em dari tanaman dan tanah disekitarnya untuk menutup.

Penyiangan dilakukan pada saat tanaman berumur 20-30 hari setelah tanam. Penyiangan pertama dilakukan bersamaan dengan kegiatan pemupukan susulan. Penyiangan kedua dilakukan setelah tanaman kedelai selesai berbunga. Penyiangan dilakukan dengan cara mencabut gulma yang tumbuh pada sekitar polibag tanaman.

Pertumbuhan tanaman kedelai yang optimal tidak akan mempunyai produktivitas yang baik bila hama dan penyakit tidak dikendalikan dengan baik. Pengendalian hama dan penyakit dilakukan dengan menggunakan pestisida anorganik.

Panen kedelai dilakukan apabila sebagian besar daun sudah menguning, tetapi bukan karena serangan hama atau penyakit, lalu gugur,buah mulai berubah warna dari hijau menjadi kuning keeoklatan dan retak-retak, atau polong sudah kelihatan tua, batang berwarna kuning agak coklat dan gundul, pada saat tanaman berumur 81 hst.

\section{Pengamatan Penelitian}

Pengamatan yang dilakukan terhadap tanaman sampel antara lain:

\section{Tinggi Tanaman $(\mathrm{cm})$}

Tinggi tanaman diukur dari pangkal batang sampai titik tumbuh tertinggi dengan satuan centimeter. Pengukuran tinggi tanaman dilakukan 1 minggu sekali sampai minggu ke 6 .

\section{Jumlah Daun}

Pada pengamatan jumlah daun per tanaman dilakukan 1 minggu sekali, umur pengamatan dimulai 15 hst. Daun yang dihitung yaitu daun yang telah terbuka penuh dan minimal $50 \%$ masih berwama hijau.

\section{Luas daun $(\mathrm{cm})$}

Pada pengamatan luas daun pertanaman dilakukan 1 kali pengamatan dengan menggunakan leaf area meter pada umur 15 hst yaitu daun yang telah terbuka penuh.

\section{Berat Segar dan Berat Kering Tajuk}

Pengamatan berat segar tajuk dilakukan pada saat panen dan berat kering tajuk dihitung setelah kering oven dengan suhu $60^{\circ} \mathrm{C}$ selama 3 hari, kemudian dengan cara menimbang daun menggunakan timbangan analitik dan dinyatakan dalam satuan gram.

\section{Jumlah Polong}

Jumlah polong tanaman dihitung setelah panen. Semua polong yang dihasilkan oleh seluruh tanaman dalam dihitung baik polong berisi rnaupun polong hampa.

\section{Berat Biji Kering Panen dan Berat Biji Kering Simpan $(g)$ \\ Berat biji kering panen dihitung pada akhir penelitian pada saat panen sedangkan berat biji}


kering simpan dihitung setelah dijemur selama 3 hari dengan kadar air $8 \%$.

7. Berat 100 Biji Kering Panen dan Berat 100

Biji Kering Simpan (g)

Berat 100 biji kering panen diperoleh dengan menimbang 100 biji kering panen dan berat 100 biji kering simpan.

\section{Analisis Data}

Data hasil pengamatan dianalisis dengan sidik ragam pada taraf kesalahan 5\% untuk mengetahui pengaruh perlakuan. Jika ada beda nyata antar perlakuan maka dilakukan uji lanjut dengan menggunakan DMRT (Duncan's Multiple Range Test) pada taraf kesalahan $5 \%$.

\section{HASIL DAN PEMBAHASAN}

Berdasarkan hasil analisis menunjukkan hahwa tidak ada beda nyata antar perlakuan terhadap pertumbuhan tinggi tanaman kedelai $(P>0.05$, Tabel 1$)$. Pengaruh yang tidak beda nyata terjadi diduga karena pupuk NPK pelet kotoran ayam sebagai pupuk organik yang slow release system dapat diserap secara sempurna oleh tanaman karena telah dibenam dan diduga telah terurai sempurna selama pertumbuhan tanaman pada media tanam yang menggunakan tanah regosol. Dalam pertumbuhan vegetatif tanaman maupun unsur hara pendukung pertumbuhan vegetatif tanaman yang lainnya terpenuhi sehingga tanaman dapat tumbuh dengan baik. Regosol merupakan tanah dimana perkembangan tanahnya selalu tergantung dari bahan induk dan topografi sehingga akan berpengaruh terhadap kesuburan, drainase, tekstur, struktur dan konsistensi partikel tanah. Seperti yang dikemukakan oleh Munir (1996) apabila bahan induk belum mengalami pelapukan, untuk mempercepat pelapukan diperlukan bahan organik, pupuk kandang atau pupuk hijau.
Tabel 1. Rerata Tinggi Tanaman, Jumlah Daun, Luas Daun, Berat Segar Tajuk, dan Berat Kering Tajuk

\begin{tabular}{lccccc}
\hline Perlakuan & $\begin{array}{c}\text { Tinggi } \\
\text { Tanaman }(\mathrm{cm}) \\
49 \mathrm{HST}\end{array}$ & $\begin{array}{c}\text { Jumlah } \\
\text { Daun (helai) } \\
63 \mathrm{HST}\end{array}$ & $\begin{array}{c}\text { Luas Daun } \\
\left(\mathrm{cm}^{2}\right)\end{array}$ & $\begin{array}{c}\text { Berat Segar } \\
\text { Tajuk }(\mathrm{g})\end{array}$ & $\begin{array}{c}\text { Berat } \\
\text { Kering Tajuk } \\
(\mathrm{g})\end{array}$ \\
\hline K0 & 142,500 & 42,333 & 132,67 & 89,71 & 36,777 \\
K1 & 142,833 & 43,000 & 147,00 & 77,74 & 35,073 \\
K2 & 153,467 & 41,000 & 124,33 & 93,69 & 31,303 \\
K3 & 144,033 & 36,333 & 152,33 & 102,61 & 33,500 \\
K4 & 142,300 & 38,667 & 161,67 & 78,97 & 33,380 \\
K5 & 140,767 & 31,000 & 130,67 & 82,43 & 23,177 \\
\hline P value & $>0.05$ & $>0.05$ & $>0.05$ & $>0.05$ & $>0.05$ \\
\hline
\end{tabular}

Hasil sidik ragam jumlah daun per tanaman dan luas juga menunjukkan tidak ada beda nyata antar perlakuan $(P>0.05$, Tabel 1$)$. Daun merupakan penghasil fotosintat utama dan bermanfaat dalam translokasi hasil fotosintesis. Menurut Wosonowati (2009), secara umum dengan meningkatnya jumlah daun dan luas daun suatu tanaman berarti aktivitas fotosintesis yang terjadi akan meningkat pula. Seperti yang dikemukakan oleh Lingga (2009) bahwa tersedianya unsur hara makro yang cukup bagi tanaman akan merangsang makin banyaknya karbohidrat yang terbentuk dan juga akan merangsang tunas baru misalnya jumlah daun. Ketersediaan unsur hara $\mathrm{N}$ di dalam tanah dapat mempengaruhi jumlah dan luas daun yang terbentuk. Selain itu jika unsur $\mathrm{N}$ dalam tanah lebih banyak dibandingkan dengan unsur-unsur lainnya, maka pertumbuhan tanaman akan mengarah pada besarnya laju pertumbuhan vegetatif, dimana permukaan daun menjadi lebih besar dan memacu proses fotosintesis tanaman. Menurut Lakitan (1995) jika kandungan hara dalam tanah cukup tersedia maka ILD (Indeks luas daun) suatu tanaman akan semakin tinggi, dimana sebagian besar asimilat dialokasikan untuk pembentukan daun yang mengakibatkan luas daun bertambah.

Berdasarkan hasil sidik ragam menunjukan bahwa perlakuan memberikan pengaruh tidak berbeda nyata terhadap berat segar dan ker- 
ing tanaman $(P>0.05$, Tabel 1$)$. Jadi dapat dikatakan bahwa pada tanaman tersebut kandungan air dan unsurnya sama. Diduga karena pemberian pupuk NPK pelet kotoran ayam tidak menyebabkan perbedaan penyerapan air dan penimbunan hasil fotosintesis. Mimbar (1991), menyatakan bahwa kelancaran proses penyerapan unsur hara oleh tanaman terutama difusi tergantung dari persediaan air tanah yang berhubungan erat dengan kapasitas menahan air oleh tanah, seluruh komponen tersebut mampu memacu proses fotosintesis secara optimal. Situmpul dan Guritno (1995) mengemukakan bahwa jumlah dan ukuran tajuk akan mempengaruhi berat brangkasan. Semakin banyak jumlah daun dan semakin tinggi tanaman, maka berat segar brangkasan akan semakin besar. Selain itu berat basah juga dipengaruhi oleh kandungan air pada sel-sel tanaman yang kadarnya dipengaruhi oleh lingkungan seperti suhu dan kelembaban udara, sehingga berat kering tanaman lebih menunjukkan status pertumbuhan tanaman.

Tabel 2. Rerata Jumlah Polong, Berat Biji Kering Panen, Berat Biji Kering Simpan, Berat 100 Biji Kering Panen, Berat 100 Biji Kering Simpan

\begin{tabular}{lccccc}
\hline Perlakuan & $\begin{array}{c}\text { Jumlah } \\
\text { Polong }\end{array}$ & $\begin{array}{c}\text { Berat Biji } \\
\text { Kering Panen } \\
(\mathrm{g} / \text { tanaman) }\end{array}$ & $\begin{array}{c}\text { Berat Biji } \\
\text { Kering Simpan } \\
(\mathrm{g} / \text { tanaman) }\end{array}$ & $\begin{array}{c}\text { Berat 100 } \\
\text { Biji Kering } \\
\text { Panen (g) }\end{array}$ & $\begin{array}{c}\text { Berat 100 } \\
\text { Biji Kering } \\
\text { Simpan (g) }\end{array}$ \\
\hline K0 & 83,000 & 20,770 & 13,837 & 18,713 & 11,660 \\
K1 & 86,000 & 23,550 & 15,837 & 20,260 & 11,763 \\
K2 & 87,000 & 26,393 & 17,703 & 20,577 & 13,293 \\
K3 & 82667 & 21,920 & 14,447 & 19,337 & 11,523 \\
K4 & 80,000 & 23,233 & 16,367 & 20,080 & 12,803 \\
K5 & 78,000 & 26,830 & 18,053 & 21,230 & 13,183 \\
\hline P value & $>0.05$ & $>0.05$ & $>0.05$ & $>0.05$ & $>0.05$ \\
\hline
\end{tabular}

Hasil sidik ragam jumlah polong menunjukan bahwa semua perlakuan memberikan pengaruh tidak berheda nyata terhadap jumlah polong tanaman kedelai $(P>0.05$, Tabel 2$)$. Perbedaan perlakuan pupuk ternyata tidak terlalu mempengaruhi jumlah polong. Diduga kandungan tanah Grumusol didalam pupuk NPK pelet kotoran ayam dapat meningkatkan KPK tanah Regosol sehingga unsur hara dan air yang ada dalam tanah dapat diserap tanaman dengan baik. Seperti yang dikemukakan oleh Supardi dkk. (1978) cit. Suhartono (2008) faktor tanah juga berperan dalam menentukan jumlah polong per tanaman pada tanaman kedelai. Perlakuan NPK Pelet kotoran ayam 1 ton/1h (K2) memiliki jumlah polong yang paling tinggi bila dibandingkan dengan perlakuan yang lain. Jumlah polong yang paling tinggi diduga pupuk NPK pelet kotoran ayam dengan takaran maksimal selain memperbaiki kondisi tanah juga mampu mensuplai unsur hara yang dibutuhkan tanaman sehingga pada dosis NPK Pelet kotoran ayam 1 ton/lh memberikan hasil yang terbaik. Unsur phospat yang terdapat pada pupuk pelet kotoran ayam mampu mempercepat pendewasaan tanaman sehingga pada dosis $\mathrm{K} 2$ memberikan jumlah jumlah polong yang lebih baik.

Berdasarkan hasil sidik ragarn terlihat bahwa semua perlakuan memberikan pengaruh tidak berbeda nyata terhadap berat kering biji panen tanaman kedelai ( $P>0.05$, Tabel 2$)$. Hal ini mengindikasikan bahwa semua imbangan pupuk yang diberikan memberi pengaruh yang sama terhadap berat kering biji panen per tanaman . Namun, NPK Pelet kotoran ayam 2,5 ton/h (K5) menunjukkan berat yang relatif lebih tinggi dibandingkan dengan perlakuan lainnya. Hal ini diduga banyaknya polong yang dihasilkan sehingga menghasilkan biji yang lebih banyak, di mana dalam hal ini pupuk yang diberikan pada tanaman kedelai cukup atau terserap oleh tanaman sehingga berat yang dihasilkan juga meningkat.

Pengaruh dosis pupuk NPK pelet kotoran 
ayam terhadap berat biji kering simpan menunjukkan bahwa perlakuan 2,5 ton/h memberikan hasil paling tinggi dengan persamaan regresi kubik $Y=1856,800+2,609 x+-002 X 2$ $+0,0000005413 x^{3}$ dengan nilai sig $=0,759$ $(75,9 \%)$ artinya $>70 \%$ sehingga regresi nyata. Nilai R2 = 0,586 yang berarti 58,6\% berat biji kering simpan kedelai dipengaruhi oleh dosis NPK pelet kotoran ayam (Gambar 1). Sedangkan 41,4\% berat biji kering simpan kedelai dipengaruhi oleh faktor lain di luar dosis pupuk NPK pelet kotoran ayam. Hal ini menunjukkan bahwa ketersediaan unsur hara dalam tanah tercukupi untuk pembentukan biji. Respon tanaman sangat tergantung pada keseimbangan ketersediaan pupuk N,P,K bagi tanaman. Melati (1990) memperlihatkan bahwa pupuk kandang ayam selain karena kandungan haranya, juga karena kemampuannya meningkatkan ketersediaan $\mathrm{P}$ bagi tanarnan menyebabkan produksi kedelai meningkat.

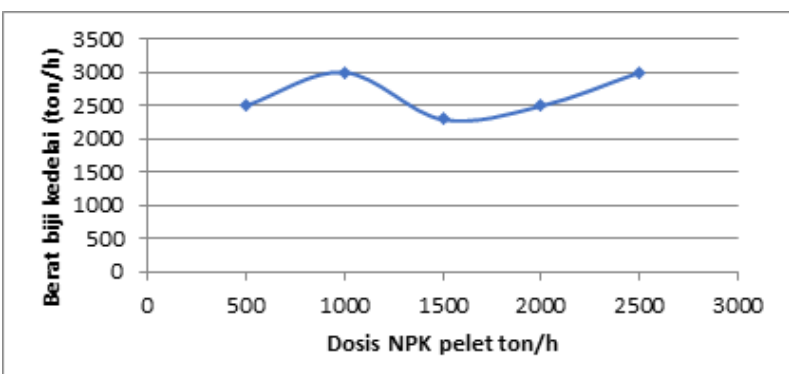

Gambar 1. Pengaruh dosis pupuk NPK pelet kotoran ayam terhadap berat biji kering simpan

Menurut Kasno dkk. (1987) komponen hasil seperti berat 100 biji lebih dominan ditentukan oleh sifat genetik tanaman dibandingkan dengan faktor lingkungan. Selanjutnya Kamil (1996) mengungkapkan bahwa tinggi rendahnya berat biji tergantung pada banyak atau sedikitnya bahan kering yang terdapat di dalarn biji, bentuk biji dan ukuran biji yang dipengaruhi oleh gen yang terdapat di dalam tanaman itu sendiri. Perlakuan pupuk NPK pelet kotoran ayam 2,5 ton/h memberi nilai relatif lebih tinggi jika dibandingkan dengan perlakuan yang lain (Tabel 2). Hal ini disebabkan pupuk. yang diberikan pada tanaman kedelai cukup atau terserap oleh tanaman sehingga berat yang dihasilkan juga meningkat. Haryanto (1985) menjelaskan fosfor dapat meningkatkan jumlah bunga yang terbentuk dan bobot kering biji kedelai.

Berat 100 biji merupakan salah satu parameter pengamatan yang erat hubungannya dengan produksi yang dicapai. Bila berat 100 biji tinggi maka semakin banyak pula hasil yang akan diperoleh. Perlakuan pupuk NPK pelet kotoran ayam 1 ton/h (K2) memberi nilai lebih tinggi jika dibandingkan dengan perlakuan yang lain tetapi untuk berat 100 biji kering panen nilai yang paling tinggi yaitu pada perlakuan NPK pelet kotoran ayam 2,5 ton/h (Tabel 2). Hal ini diduga bahwa penggunaan pupuk NPK pelet kotoran ayam 1 ton/h memenuhi kebutuhan nutrisi kedelai yang optimal dan lebih efisien sehingga memberikan berat 100 biji kering simpan yang relatif lebih tinggi selanjutnya pada perlakuan NPK pelet kotoran ayam 2,5 ton/h diduga lebih banyak memiliki kandungan air yang menyebabkan pada berat 100 biji kering simpang memiliki nilai rendah dibandingkan dengan perlakuan pupuk NPK pelet kotoran ayam 1 ton/h meskipun pada semua perlakuan tidak berbeda nyata. Kemudian hasil paling rendah ditunjukkan oleh perlakuan pupuk NPK pelet kotoran ayam 1,5 ton/h. Menurut Mimbar (1991) jumlah dan ukuran biji maksimal ditentukan oleh faktor genetik serta kondisi yang dialami selama pengisian biji. Pada saat pengisian polong, maka polong akan menjadi daerah penyaluran asimilasi. Sebagian besar asimilasi akan digunakan untuk meningkatkan bobot biji. 


\section{SIMPULAN}

Penggunaan pupuk NPK pelet kotoran ayam $500 \mathrm{~kg} / \mathrm{h}$ temyata lebih efektif dalam meningkatkan pertumbuhan dan hasil tanaman kedelai pada tanah regosol. Penggunaan pupuk pelet pada tanah Regosol marnpu menggantikan pupuk rekornendasi anorganik, pupuk NPK pelet kotoran ayarn $500 \mathrm{~kg} / \mathrm{h}$ rnampu mensubstitusi penggunaan Urea sebanyak 80\%, SP-36 53,3\% dan $\mathrm{KCl} 60 \%$.

Penelitian ini perlu dikaji lebih lanjut pada kondisi lapangan (lahan) dan penelitian ini juga perlu dikaji lebih lanjut tentang pernupukan NPK pelet kotoran ayarn pada budidaya kedelai di musirn kemarau dan penghujan.

\section{DAFTAR PUSTAKA}

Haryanto.1985. Pengaruh Pemupukan Fosfor pada Tiga M etoda Pengolahan Tanah terhadap Hasil dan Komponen Hasil Tanarnan Kedelai (Glycine max (L) Merr.). Laporan Karya Ilmiah. Jurusan Budidaya Pertanian. Fakultas Pertanian. Insititut Pertanian Bogor

Helmi. 2013. Perubahan beberapa sifat fisika regosol dan hasil kacang tanah akibat pemberian bahan organik dan pupuk fosfat. Journal SAINS Riset 1 (18) : 71-75.

Isroi. 2009. Pupuk Organik Pelet. http://isroi. coml2009/07/19/pupuk-organik- pelet-pop-2/. Diakses Tanggal21 juni 2013.

Kamil, J. 1996. Teknologi Benih. Angkasa Raya. Padang.

Kasno, A. Bahri, A.A. Mattjik, S. Solahudin, S. Somaatmadja, dan Subandi. 1987.

Telaah interaksi genotipe dan lingkungan pada kacang tanah. Penelitian

Palawija 6 (2) : 81-88.

Lakitan, B. 1995. Fisiologi Turnbuhan. Grafindo Persada. Jakarta.

Lingga, 2002. Hidroponik: Bertanam Tanpa Tanah. Penebar Swadaya: Jakarta.

Manwan. l., dan Sumamo. 1991. Kebijakan Penelitian Bagi pengembangan Produksi Kedelai. Seminar dan Workshop Pengembangan Produksi Kedelai Puslitbang. Tanaman Pangan dan PAU Bioteknologi IPB, Bogor.

Melati, M. 1990. Tanggap Kedelai (Glycine max (L.) Merri/) Terhadap Pupuk

Mikro Zn, Cu, B pada Beberapa Dosis Pupuk Kandang di Tanah Latosol.

Mimbar,S.M. 1991. Pengaruh Kerapatan Terhadap Keguguran Organ-Organ Reproduksi Retensi Polong Dan Hasil Kedelai. (Skripsi) Fakultas Pertanian Universitas Brawijaya. Malang.
Munir, M. 1996. Tanah-tanah Utama Indonesia. Pustaka Jaya. Jakarta 315 hal.

Sitompul, S.M. dan B. Guritno. 1995. Analisis Pertumbuhan Tanaman. UGM- Press. Yogyakarta.

Suhartono, R. A., Sidqi Zaed ZM dan Ach Khoiruddin. 2008. Pengaruh interval pemberian air terhadap pertumbuhan dan hasil tanaman kedelai (Glicine Max (L) Merril) pada berbagai jenis tanah. Jumal Embryo 5 (1): 36-41

Suswono. 2013. http://bisniskeuangan.kompas.com. Diakses 28 Februari 2013. Sutejo. 2002. Pupuk dan Cara Pemupukan. Rineka Cipta. Jakarta. 